\title{
Genetic Evidence of Intra-cultivar Variability within Iberian Olive Cultivars
}

\author{
Maria Susana Lopes and Duarte Mendonça \\ Universidade dos Açores, Departamento de Ciências Agrárias, Terra-Chã, \\ 9701-851 Angra do Heroísmo, Portugal
}

Kristina M. Sefc

Institut für Zoologie, Karl-Franzens-Universität Graz, Universitätsplatz 2, A-8010 Graz, Austria

\section{Fabíola Sabino Gil and Artur da Câmara Machado ${ }^{1}$ \\ Universidade dos Açores, Departamento de Ciências Agrárias, Terra-Chã, 9701-851 Angra do Heroísmo, Portugal}

Additional index word. Olea europaea, germplasm management, microsatellites, SSR, intravarietal polymorphism, cultivar families

\begin{abstract}
A collection of 130 olive samples, originating from diverse areas in Europe and corresponding to 67 different cultivars denominations, was genotyped at 14 microsatellite loci. In total, 135 alleles with a mean number of 9.6 alleles per locus were detected. All but 30 accessions showed unique genotypes. Several cases of synonymy listed in the FAO database of olive germplasm could not be confirmed, as different allelic profiles were obtained from putatively synonymous cultivars. The existence of homonyms or mislabeled samples in olive germplasm collections was evidenced by allele differences of up to $60 \%$ between samples of the same denomination. An allele-sharing phenogram of the analyzed genotypes revealed several cultivars with high levels of intra-varietal polymorphism, as well as cultivar families consisting of closely related cultivars with similar denominations. Our work shows that the current designations of olive cultivars fall short of describing the genetic variability among economically important plant material. A thorough investigation of the existing variability will prove of major importance for both management and economic production of olive trees.
\end{abstract}

Olive (Olea europaea L.) is one of the most ancient cultivated trees and its domestication probably occurred in the Near-East (Zohary and Hopf, 1994). Olive cultivation, which is widespread throughout the Mediterranean basin, is important both to the rural economy and to the environmental balance of the producing regions.

The great number of olive cultivars grown all over the world, estimated as about 1200 with over 3000 synonyms (Rugini and Lavee, 1992) and the increasing demand for olive oil(Besnard et al., 2001a; http://www.internationaloliveoil. org/downloads/consomation1_ang.PDF) com-

\footnotetext{
Received for publication 15 Oct. 2003. Accepted for publication 1 Apr. 2004. We thank V. Savino and M. Saponari from the University of Bary (Italy), the Fábrica Torrejana de Azeites S.A. (Portugal), PLANSEL-Viveiros Jorge Böhm Lda (Portugal), Doutor Pedro Fevereiro from the Faculdade de Ciências da Universidade de Lisboa (Portugal), and the olive germplasm collection of the Estação Nacional de Melhoramento de Plantas in Elvas (Portugal) for the plant material. This work has been carried out with financial supportfrom the Portuguese Ministério da Ciência e Tecnologia PRAXIS XXI POCTI/36162/ AGR/2000 and by the Commission of the European Communities, specifically RD programme "Quality of Life and Management of Living resources" (QLK1-CT-2002-02386) “Traceability of Origin and Authenticity of Olive Oil by Combined Genomic and Metabolic Approaches" (OLIV-TRACK). It does not necessarily reflect the views and in no way anticipates the commission's future policy in this area.

${ }^{1}$ To whom reprint requests should be addressed; e-mail amachado@ angra.uac.pt.
}

bined, increase the importance of the correct identification of the different varieties.

The large amount of cultivars causes a huge problem in the management of germplasm collections and genomic traceability of olive oils, as there is a considerable uncertainty about the names of many cultivars and as olive cultivars are morphologically very similar (Cipriani et al., 2002). Moreover, it was shown that genetic variability could occur within the same cultivated populations (Gregoriou, 1996; Wiesman et al., 1998), which could justify heterogeneity in production and quality traits (Besnard et al., 2001a).

Clonal vegetative propagation has been practised in olives for several thousand years (Garcia-Díaz et al., 2003), using cuttings that were planted directly, or more recently, grafted onto indigenous oleasters (Amane et al., 1999). The identification of olive tree cultivars has been traditionally carried out by morphological and agronomic traits, which are influenced by environmental or cultivation factors (Hernández et al., 2001), increasing the risk of accidental misidentification or mislabeling.

The recognition of the Protected Designation of Origin [Regulations (EEC) No. 2081/92 and (EEC) No. 2082/92] for oliveoilincreased theneed of a reliable verification of cultivars being grown, particularly to nurserymen and growers.

Microsatellite markers or simple-sequence repeats (SSRs) are a suitable tool for cultivar characterization and a number of loci have already been identified for olive (Carriero et al., 2002; Cipriani et al., 2002; Rallo et al., 2000;
Sefc et al., 2000). The combination of data of several highly polymorphic microsatellite loci results in individual allelic profiles for different genotypes, while their codominant manner of inheritance allows parentage analysis (Sefc et al., 1997). The general reproducibility of SSR genotyping results between laboratories (Jones et al., 1998) supports the establishment of an olive worldwide genotyping database based on microsatellite data, as suggested for other species (Botta et al., 1995).

In the present study 130 individuals were typed with 14 SSR to evaluate the genetic variability in olive germplasm (between and within cultivars) mainly in the Iberian Peninsula.

\section{Material and Methods}

Eighty two accessions corresponding to 36 Portuguese varieties of several geographical locations were chosen. Also several other Iberian and Mediterranean cultivars were selected for comparison, yielding a total of 130 samples (Table 1).

DNA was extracted from leaves following the protocol described by Fabbri et al. (1995). The plants were genotyped for 14SSR loci: ssrOeUADCA1, ssrOeUA-DCA3, ssrOeUA-DCA4, ssrOeUA-DCA5, ssrOeUA-DCA7, ssrOeUADCA8, ssrOeUA-DCA9, ssrOeUA-DCA11, ssrOeUA-DCA13, ssrOeUA-DCA14, ssrOeUADCA15, ssrOeUA-DCA16, ssrOeUA-DCA17, and ssrOeUA-DCA18 (Sefc et al., 2000).

Polymerase chain reactions (PCR) were carried out in a total volume of $20 \mu \mathrm{L}$ containing $50 \mathrm{ng}$ DNA, $1.5 \mathrm{~mm} \mathrm{MgCl}, 100 \mu \mathrm{M}$ of each dNTP, 10 pmol of each primer and 0.5U Taq DNA polymerase in storage buffer B (Promega) in supplied reaction buffer. Reactions were performed in a UNO II Biometra thermocycler with the temperature regime described by Sefc et al. (2000). PCR products were analyzed in an automated sequencer (ABI Prism 310 genetic analyser, PE Applied Biosystems) and fragment lengths were determined with the help of internal size standards (Genescan 350TAMRA size standard, PE Applied Biosystems).

Gene diversity $\left(H_{E}\right)(\mathrm{Nei}, 1973)$, observed heterozygosity $\left(H_{O}\right)($ Brookfield, 1996), probability of identity (PI) (Paetkau et al., 1995) and estimation of null allele frequency from the heterozygote deficiency (r) (Brookfield, 1996) were calculated using IDENTITY (Wagner and Sefc, 1999). This program was also used to detect identical genotypes.

Deviations of observed heterozygosity values from Hardy-Weinberg expectations were analyzed using GENEPOP (Raymond and Rousset, 1995). Genetic distances between cultivars were calculated in MICROSAT (Minch, 1997) as 1-proportion of shared alleles and a phenogram was drawn using the UPGMA algorithm in PHILIP (Felsenstein, 1989) and the program TREEVIEW (Page, 1996).

\section{Results}

Characterization of 14 SSR markers in olive cultivars from different origins. Among the 130 accessions comprising 67 different denominations, 100 different SSR profiles were 
Table 1. Olive cultivars studied. The number in parentheses represents the number of individuals analyzed for each accession and the letters indicate the country of origin of the denominations $(\mathrm{Fr}=\mathrm{France} ; \mathrm{Gr}$ = Greece It = Italy; Mo = Morocco; Pt = Portugal; Sp = Spain; Tu = Tunisia; Tk = Turkey).

\begin{tabular}{|c|c|}
\hline Alberquia (3) (Sp) & Lianolia (Gr) \\
\hline Arbequina $(\mathrm{Sp})$ & Maçanilha (Sp) \\
\hline Ascolana (2) (It) & Maçanilha Carrasquenha de Almendralejo (3) (Pt) \\
\hline Ayvalik (Tk) & Maçanilha de Elvas $(\mathrm{Pt})$ \\
\hline Azeiteira $(5)(\mathrm{Pt})$ & Maçanilha de Jaen (Sp) \\
\hline Bical Castelo Branco (Pt) & Maçanilha de Tavira (4) (Pt) \\
\hline Bico de Corvo $(\mathrm{Pt})$ & Madural (2) (Pt) \\
\hline Blanqueta (3) (Sp) & Manzanilha (Sp) \\
\hline Borrenta $(2)(\mathrm{Pt})$ & Meski (Tu) \\
\hline Carrasca de Trás-os-Montes $(\mathrm{Pt})$ & Mora (Sp) \\
\hline Carrasquenha $(3)(\mathrm{Pt})$ & Negrinha (3) (Pt) \\
\hline Carrasquenha de Elvas (Pt) & Negrita $(\mathrm{Pt})$ \\
\hline Carrasquinha $(\mathrm{Pt})$ & Negroa do Estanqueiro (Pt) \\
\hline Cima di melfi (It) & Nocellara messinese (It) \\
\hline Cipressino (It) & Nociara (It) \\
\hline Cobrançosa (4) (Pt) & Pendolino (It) \\
\hline Conserva das Barrancas (Pt) & Picholine (2) (Fr) \\
\hline Conserva de Elvas (3) (Pt) & Picholine Marocaine (Mo) \\
\hline Coratina (2) (It) & Pico Limon (Sp) \\
\hline Cordovil $(3)(\mathrm{Pt})$ & Picual (4) (Sp) \\
\hline Cordovil de Castelo Branco (4) (Pt) & Planalto $(\mathrm{Pt})$ \\
\hline Cordovil de Elvas (4) (Pt) & Quinta do Portado (Pt) \\
\hline Cordovil de Moura $(\mathrm{Pt})$ & Redondil (4) (Pt) \\
\hline Cordovil de Serpa (4) (Pt) & Sant'Agostino (It) \\
\hline Cornezuelo (3) (Sp) & Santulhana (Sp) \\
\hline Cornicabra (Sp) & Tentilheira $(\mathrm{Pt})$ \\
\hline Frantoio (3) (It) & Termite di Bitetto (It) \\
\hline Galega $(8)(\mathrm{Pt})$ & Uovo di Piccione (Tu) \\
\hline Galega Grada de Serpa $(\mathrm{Pt})$ & Verde Verdelho (3) (Pt) \\
\hline Galego Évora $(\mathrm{Pt})$ & Verdeal Alentejana (3) (Pt) \\
\hline Golosinha $(\mathrm{Pt})$ & Verdeal de Elvas $(\mathrm{Pt})$ \\
\hline Gordal (Sp) & Verdeal de Serpa (3) (Pt) \\
\hline Hojiblanca (2) (Sp) & Verdeal Transmontana $(\mathrm{Pt})$ \\
\hline Leccino (2) (It) & \\
\hline
\end{tabular}

obtained. A total of 135 alleles were detected, ranging from 4 to 16 alleles (Table 2), with a mean of 9.6 alleles per locus.

Probabilities of identity varied between loci due to uneven allele frequency distributions. The highest information content was provided by locus ssrOeUA-DCA16, while high PI values were estimated for loci ssrOeUA-DCA14 and ssrOeUA-DCA5. In ssrOeUA-DCA 14 the two most common alleles account for $90 \%$ of the frequencies, while the remaining $10 \%$ were shared by three alleles. In ssrOeUA-DCA5 the most common allele has a frequency of $75 \%$, while the remaining five alleles have frequencies between $1 \%$ and $12 \%$. The combined probability for identical genotypes across all loci is low with $9.4 \times 10^{-13}$.
Genetic Resources Service at www.fao.org/ag/ agp/agps/seed/olive.htm) were compared with the data obtained by the characterization of the 130 accessions at 14 SSR loci (data available at www.angra.uac.pt/biotecagri/publicacoes/htm). The phenogram in Fig. 1 illustrates the genetic similarities among the analyzed cultivars.

'Alberquina', also know as 'Arbequina' according to theFAO's olive germplasm database, is one of the most widely used Spanish cultivars for oil production. Genotypes of three samples with the denomination 'Alberquina' were analyzed and compared with one sample of 'Arbequina'. Although the genotypes of the four accessions differed from one another at one to four alleles, the 'Alberquina' and 'Arbequina' samples grouped together to the exclusion of all other cultivars in the phenogram, forming a cultivar family.

Similarly, intra-cultivar variability with differences in up to four alleles was observed in 'Picual', 'Conserva de Elvas', 'Verde Verdelho', 'Ascolana', 'Coratina', 'Cobrançosa' and 'Picholine'.

An interesting case is 'Galega', the most widely used cultivar for oil production in Portugal, accounting for about $80 \%$ of the orchards. Eight individuals under this denomination were analyzed and showed unique SSR profiles. Seven of the eight genotyped accessions differed from each other in only 1 to 2 alleles, while the other sample differed from them in up to 10 alleles. Nevertheless these 8 accessions and another 'Galega' accession, 'Galega Grada de Serpa', which differed from the other 'Galegas' in up to 15 alleles out of 28, clustered in the same group. 'Galego de Évora', also differs from the 'Galega' group in up to 15 alleles, but did not cluster within the 'Galegas', although its name would suggest an affiliation within the group.

A different pattern was found in the 'Maçanilha' cultivar. 'Maçanilha de Jaen', originally from Spain, is a cultivargrown in Alentejo(Portugal). It is used with 'Maçanilha Carrasquenha de Almendralejo' for the production of canned fruits. The allelic profiles of 'Maçanilha de Jaen' and of two individuals of 'Maçanilha Carrasquenha de Almendralejo' as well as that of 'Maçanilha', a cultivar widely distributed in Spain, were identical. Another sample of 'Maçanilha Carrasquenha de Almendralejo' revealed an SSR profile very similar to the other samples under the

Table 2. Genetic parameters of the studied loci in 130 samples. The table shows the number and size range of alleles detected, the probability of finding identical genotypes for each locus and for all loci combined, expected and observed heterozygosity, and the probability of null alleles at each locus.

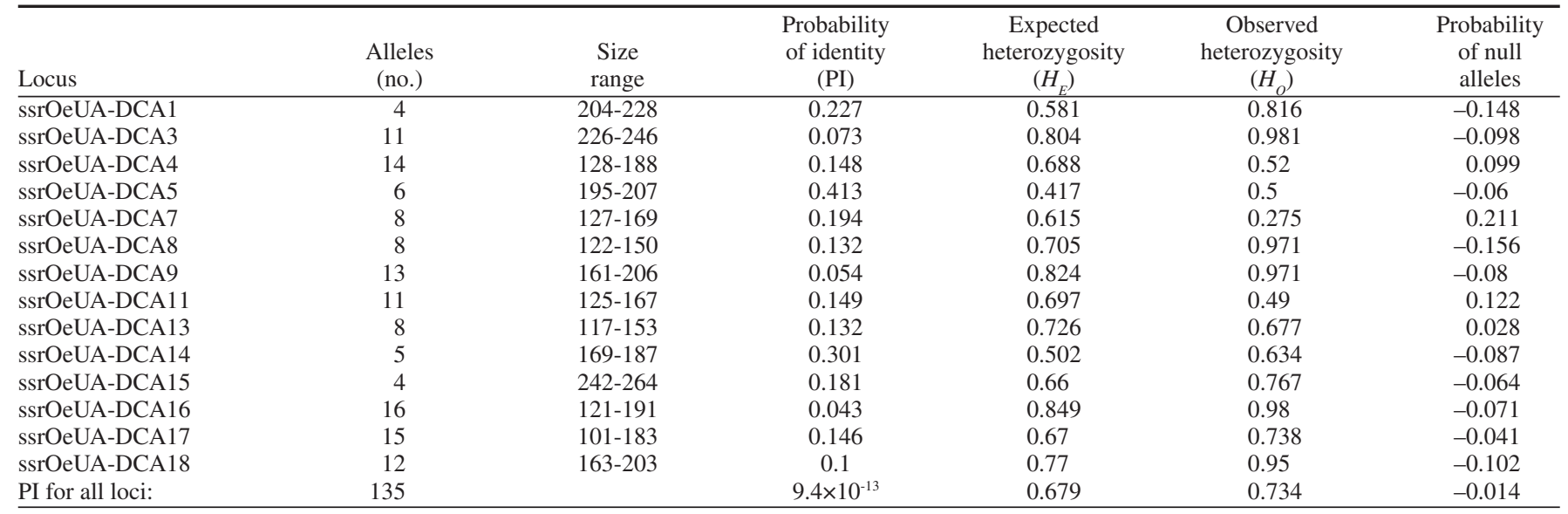




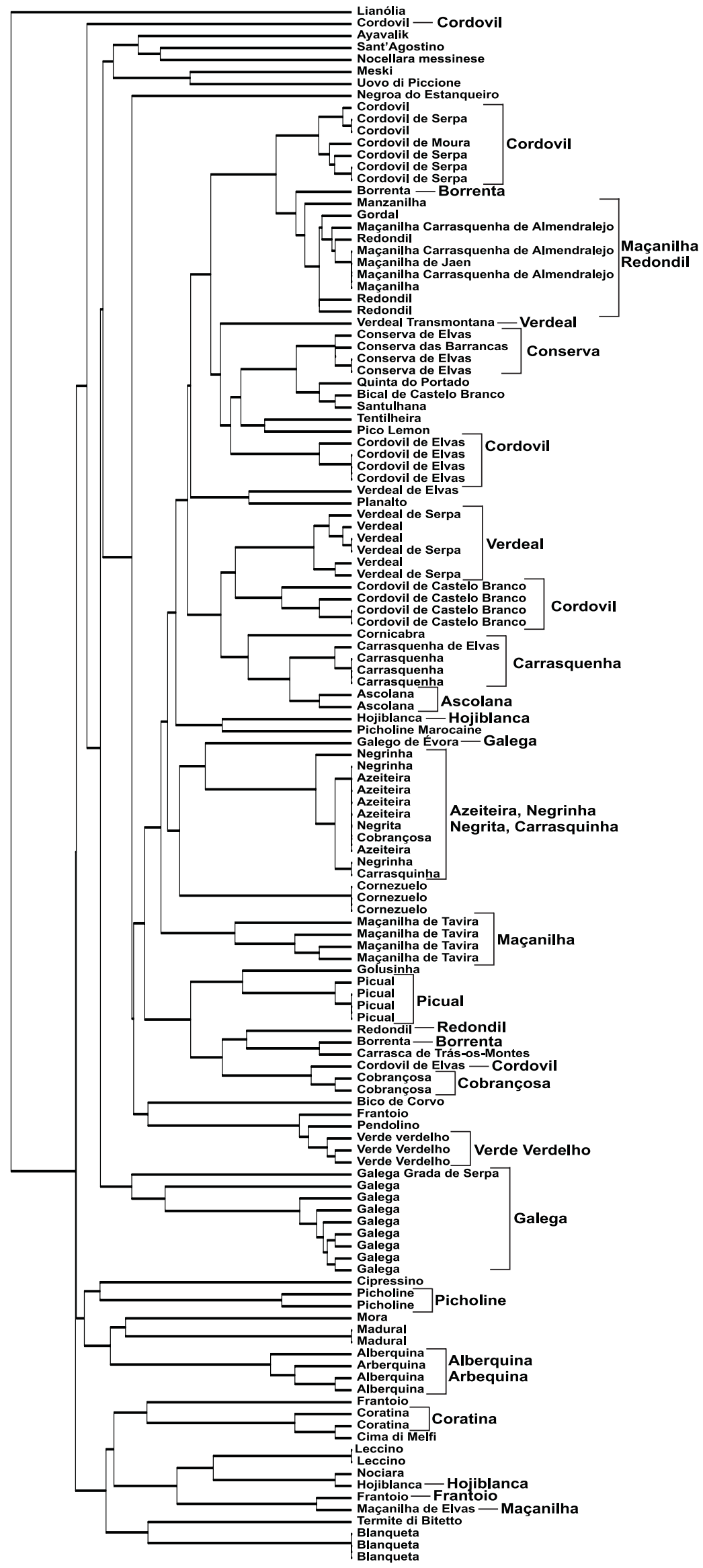

Fig. 1. UPGMA phenogram of genotyped olive samples. Cultivar families, synonymous and homonymous cultivars are highlighted. same name, differing in only one allele at locus ssrOeUA-DCA17. 'Manzanilha', the Spanish counterpart of 'Maçanilha', had a different allelic profile from its Portuguese synonym at locus ssrOeUA-DCA13. 'Maçanilhade Tavira', grown in Algarve (Southern Portugal) and 'Maçanilha de Elvas', grown in Alentejo (Central/Portugal) differ substantially from each other and the other 'Maçanilhas'.

For a survey of the genetic diversity within the 'Verdeal' group, three 'Verdeal Alentejana', three 'Verdeal de Serpa', one 'Verdeal de Elvas' and one 'Verdeal Transmontana' were genotyped. 'Verdeal Transmontana' is grown in the North of Portugal, while the other 'Verdeal' samples are grown in Alentejo in Central/Southern Portugal. In this case the SSR profiles obtained were different for each sample within and between cultivars, except for identical genotypes for one 'Verdeal Alentejana' and one 'Verdeal de Serpa' accession and thus the 'Verdeal' accessions were placed in three clades in the phenogram.

Anotherinteresting case is 'Cordovil', which has different denominations according to its place of origin. In this study one 'Cordovil de Moura', three 'Cordovil', four 'Cordovil de Castelo Branco', four 'Cordovil de Elvas' and four 'Cordovil de Serpa' were genotyped. In FAO's olive germplasm database 'Cordovil de Serpa' is described as a synonym of 'Bico de Corvo', from which one accession was analyzed. Within 'Cordovil' denominations, several different allelic profiles were obtained. 'Cordovil' samples displayed three genotypes, with one accession identical to one of the 'Cordovil de Serpa' genotypes, another accession closely related to the latter two (two alleles difference) and the third accession differing in up to 17 alleles from the 'Cordovil' samples. 'Cordovil de Elvas' showed two genotypes differing in two alleles, 'Cordovil de Serpa', had three genotypes differing at only one allele and 'Cordovil de Castelo Branco' also displayed three genotypes, with differences of up to six alleles. In consequence of the genetic variability of the 'Cordovil' cultivar family, the accessions were placed in five different clades in the phenogram. The synonymy of 'Bico de Corvo' with 'Cordovil de Serpa' could not be confirmed.

Several other accessions with identical names were revealed to be homonymous in that they showed little genetic similarity and thus were placed in different positions in the phenogram. For example, individuals of 'Borrenta', 'Frantoio' and 'Hojiblanca' differed in 14,26 , and 23 alleles respectively. Homonymy was also found in accessions of 'Redondil', as three samples, differing in only one allele each, clustered together, while a fourth sample differing in 14 alleles was grouped separately.

According to the FAO olive germplasm database 'Azeiteira', an important cultivar for oil production in Portugal, and 'Blanqueta', one of the most interesting varieties for the production of oil in Spain, are synonyms. However, genotyping of five 'Azeiteira' and three 'Blanqueta' individuals refuted synonymy of these cultivars. Samples within each denomination displayed identical microsatellite profiles, but only 12 out of 28 alleles were shared between 
the denominations. Surprisingly, one accession each of 'Negrita', 'Negrinha' and 'Cobrançosa' showed the same SSR profile as 'Azeiteira', suggesting synonymy or extensive mislabeling of our cultivars. The other two 'Negrinha' samples are closely related to the Azeiteira group but differ from one another in one allele.

'Carrasquenha' and 'Carrasquinha', two Portuguese cultivars used for the production of canned fruits are also listed as the same cultivar in the olive germplasm database. Three individuals of 'Carrasquenha' showed identical genetic profiles, which differed in 10 alleles from the genotype obtained from 'Carrasquinha'. 'Carrasquinha', for its part, displayed the same genotype as one sample of 'Negrinha', an important cultivar for the production of canned fruits in Portugal, and was placed next to the 'Azeiteira' group in the phenogram.

'Carrasquenha' differs in only one allele from 'CarrasquenhadeElvas', indicating ahigh genetic similarity between the two cultivars. The latter variety originates from Elvas, one of the most important olive growing regions in Portugal.

'Madural', 'Cornezuelo' and 'Cornicabra' are regarded as synonyms by the FAO olive germplasm database. However, this hypothesis was not confirmed in our analysis, as the 3 cultivars displayed SSR profiles differing in up to 17 alleles.

Similarly, 'Santulhana' and 'Gordal' are considered two denominations for the same cultivar in FAO's olive germplasm database, while this study revealed a considerable genetic distance between these two cultivars, as 9 out of 28 alleles were different between the two samples.

\section{Discussion}

When considering long term breeding programs in fruit trees, studies dealing with the structure of genetic diversity may give some insights about the selection of cultivated forms, and this may lead to a better management of their diversity (Besnardetal., 2001b). Genetic diversity has been assessed in many species with microsatellites, whose major applications has been the identification and the distinction of cultivars. The level of polymorphism and the associated information content is a crucial criterion for the choice of a particular set of loci. With up to 16 alleles, the number of alleles obtained at the loci used in this study is higher than those reported by other authors (Carriero et al., 2002; Cipriani et al., 2002; Rallo et al., 2000) where three to nine alleles per locus were reported. However, marker polymorphism also varies according to the number and origin of the plants analysed. Co-ancestry of cultivars may reduce the genetic variability of a cultivar group dramatically.

Our study describes intra-varietal polymorphism in a number of olive cultivars, with differences in up to $15 \%$ of the analyzed alleles. Cases of cultivars with even higher genetic distances between accessions are ascribed to recent or past mislabeling (homonymy). Intra-cultivar polymorphism in olives has already been reported by Cipriani et al. (2002), where differences in $\leq 2$ loci out of 30 were considered as somatic mutations occurring in the process of vegetative propagation. With the high level of intra-varietal polymorphism described in the present study, olives pose a stark contrast to another long cultivated, woody crop, the grapevine. While many grapevine cultivars have been propagated vegetatively throughout many centuries, only a few cases of intra-varietal polymorphism (Silvestroni et al., 1997; Vignani et al., 2002) and clonal polymorphism (Boursiquot, 2003) have been reported. While the genotypic stability of grapevine cultivars allowed the reconstruction of ancient crosses (Bowers and Meredith, 1997, Bowers etal., 1999, Lopes etal., 1999, Sefc etal., 1998), the determination of the exact pedigrees of olive cultivars and cultivar families will be complicated by the variability within cultivar lines, as it appears that ancient genotypes cannot necessarily be expected to have been maintained in the olive cultivars without mutation. Differences in the stringency of the selection and propagation procedure between grapevines and olives may account for the observed difference in genotypic stability of those two crops. Alternatively, mutation rates may differ between the two crops and thus produce unequal variability levels under similar agricultural circumstances and in comparable time scales.

Germplasm variability in olives may have been shaped by the century-long practice of local selection and propagation of spontaneous seedlings, and only recently, efforts have been undertaken to describe the existing gene pool. For the identification of closely related genotypes, synonyms and homonyms, genetic marker analysis will be of indispensable value. The cultivars investigated in this study are only a small part of the world's cultivar ensemble. The genetic characterization of a larger number of cultivars will not only verify and identify more homonymous and synonymous cultivars, but will also reveal more information about the genetic relationship between them.

\section{Literature Cited}

Amane, M., R. Lumaret, V. Hany, N. Ouazzani, C. Debain G. Vivier, and M.F. Deguilloux. 1999. ChloroplastDNA variation in cultivated wild olive (Olea europaea L.). TAG 99:133-139.

Besnard, G., C. Breton, P. Baradat, B. Khadari, and A. Bervillé. 2001a. Cultivar identification in olive based on RAPD markers. J. Amer. Soc. Hort. Sci. 126(6):668-675.

Besnard, G., P. Baradat, and A. Bervillé. 2001b. Genetic relationships in the olive (Olea europaea L.) reflect multilocal selection of cultivars. TAG 102:251-258.

Botta, R., N.S. Scott, I. Eynard, and M.R. Thomas. 1995. Evaluation of microsatellite sequence-tagged site markers for characterizing Vitis vinifera cultivars. Vitis 34:99-102.

Boursiqout, J.-M. 2003. Molecular expression of clona variability in grapevine. $1^{\text {st }}$ Intl. Symp. Grapevine. Lisbon, 30 June-2 July.

Bowers, J., J.M. Boursiquot, P. This, K. Chu, H. Johansson, and C. Meredith. 1999. Historical genetics: the parentage of Chardonnay, Gamay, and other wine grapes of northeastern France. Science 285:1562-1565.

Bowers, J. and C. Meredith. 1997. The parentage of a classic wine grape Chardonnay Sauvignon. Nature 16:84-87.

Brookfield, J.F.Y. 1996. A simple new method for estimating null allele frequency from heterozygote deficiency. Mol. Ecol. 5:453-455.

Carriero, F., G. Fontanazza, F. Cellini, and G. Giorio. 2002. Identification of simple sequence repeats (SSRs) in olive (Olea europaea L.). Theor. Appl. Genet. 104:301-307.

Cipriani, G., M.T. Marrazzo, R. Marconi, A. Cimato, and
R. Testolin. 2002. Microsatellite markers isolated in olive (Olea europaea L.) are suitable for individual fingerprinting and reveal polymorphism within ancient cultivars. Theor. Appl. Genet. 104:223-228.

Fabbri, A., J.I. Hormaza, and V.S. Polito. 1995. Random amplified polymorphic DNA analysis of olive (Olea europaea L.) cultivars. J. Amer. Soc. Hort. Sci. 120:538-542.

Felsenstein, J. 1989. PHYLIP- Phylogeny inference package. Cladistics 5:164-166.

Garcia-Díaz, A., R. Oya, A. Sánchez, and F. Luque. 2003. Effect of prolonged vegetative reproduction of olive tree cultivars (Olea europaea L.) in mitochondrial homoplasmy and heteroplasmy. Genome 46:377-381.

Gregoriou, C. 1996. Assessment of variation of landraces of olive tree in cyprus. Euphytica 87:173-176.

Hernández, P., R. de la Rosa, L. Rallo, G. Dorado, and A. Martín. 2001. Development of SCAR markers in olive (Olea europaea) by direct sequencing of RAPD products: Applications in olive germplasm evaluation and mapping. TAG 103:788-791

Jones, C.J., K.J. Edwards, C. van der Wiel, B.L. Vosman, M. Matthes, A. Daly, P. Bettini, M. Buiatti, E. Maestri, N. Marmiroli, J. Rueda, A. Vazquez, and A. Karp. 1998. Reproducibility testing of SSRs by a network of European laboratories. In: Karp A., P.G. Isaac, and D.S. Ingram (eds.). Molecular tools for screening biodiversity: Plants and animals. Chapman \& Hall, London, U.K.

Lopes, M.S., K.M. Sefc, E. Eiras Dias, H. Steinkellner, M. Laimer da Câmara Machado, and A. da Câmara Machado. 1999. The use of microsatellites for germplasm management in a Portuguese grapevine collection. Theor. Appl. Genet. 99:733-739.

Minch, E. 1997. MICROSAT. version 1.5b. Stanford Univ. Medical Center, Stanford, Calif.

Nei, M. 1973. Analysis of gene diversity in subdivided populations. Proc. Natl. Acad. Sci. 70:3321-3323.

Paetkau, D., W. Calvert, I. Stirling, and C. Strobeck. 1995. Microsatellite analysis of population structure in Canadian polar bears. Mol. Ecol. 4:347-358.

Page, R.D.M. 1996. TREEVIEW:An application to display phylogenetic trees on personal computers. Comp Applic Biosci 12:357-358

Rallo, P., G. Dorado, and A. Martin. 2000. Development of simple sequence repeats (SSRs) in olive tree (Olea europaea L.). Theor. Appl. Genet. 101:984-989.

Raymond, M. and F. Rousset. 1995. GENEPOP (version 1.2): Population genetics software for exact tests and ecumenicism. J Hered. 86:248-249.

Rugini, E. and S. Lavee. 1992. Olive. In: F.A. Hammerschlag and R.E. Litz (eds.). Biotechnology of perennial fruit crops, p. 371-382. CAB Intl., Wallingford, U.K.

Sefc, K.M., M.S. Lopes, D. Mendonça, M. Rodrigues dos Santos, M. Laimer da Câmara Machado, and A. da Câmara Machado. 2000. Identification of microsatellite loci in olive (Olea europaea) and their characterization in Italian and Iberian olive trees. Mol. Ecol. 9:1171-1173.

Sefc, K.M., H. Steinkellner, J. Glössl, S. Kampfer, and F. Regner. 1998. Reconstruction of a grapevine pedigree by microsatellite analysis. Theor. Appl. Genet. 96:1-5.

Sefc, K.M., H. Steinkellner, H. Wagner, J. Glössl, and F. Regner. 1997. Application of microsatellite markers to parentage studies in grapevine. Vitis 36:179-183.

Silvestroni, O., D. DiPietro, C. Intrieri, R. Vignani, I. Filippetti, C. DelCasino, M. Scali, and M. Cresti. 1997 Detection of genetic diversity among clones of cv. Fortana (Vitis vinifera L.) by microsatellite DNA polymorphism analysis. Vitis 36:147-150.

Vignani, R., M. Scali, E. Masi, and M. Cresti. 2002. Genomic variability in Vitis vinifera L. "Sangiovese" assessed by microsatellite and non-radioactive AFLP test. Electronic J. Biotechnol. 5:1-11.

Wagner, H.W. and K.M. Sefc. 1999. IDENTITY1.0.Centre for Appl. Genet., Univ. Agr. Sci., Vienna.

Wiesman, Z., N. Avidan, S. Lavee, and B. Quebedeaux. 1998. Molecular characterization of common olive varieties in Israel and West Bank using randomly amplified polymorphic DNA (RAPD) markers. J. Amer. Soc. Hort. Sci. 123(5):837-841

Zohary, D. and M. Hopf. 1994. Domestication of plants in the Old World. 2nd ed. Clarendon Press, Oxford, U.K. 